LI Shanmin, ZHOU Xiaochun

\title{
Firm characteristics, industry characteristics and acquisition strategy: An empirical study of Chinese listed firms
}

\author{
(C) Higher Education Press and Springer-Verlag 2009
}

\begin{abstract}
This paper studies 148 related and 169 unrelated acquisition cases conducted by Chinese listed firms from 2001 to 2004 and explores firm and industry characteristics of these firms prior to their acquisition. Results show that there are significant pre-acquisition differences between firms pursuing related acquisition and firms pursuing unrelated acquisition in terms of firm performance, business risk, firm size, proportion of state shares and degree of diversification profile. Except for differences in internal capital as represented by undistributed profit per share, there is no significant difference in other aspects of available resources and industry performance.
\end{abstract}

Keywords firm performance, industry performance, acquisition type, diversification acquisition

摘要 以 2001 年至 2004 年的我国上市公司中的 148 起相关并购事件和 169 起无关 多元化并购事件为样本, 考察了相关并购公司以及无关多元化并购公司并购前的公 司特征和行业特征。研究发现：相关并购的公司与无关多元化并购的公司并购前在 公司绩效、公司经营风险/公司规模、国有股比例以及多元化状况方面存在显著差异， 而公司可利用资源中除了每股未分配利润所代表的内部资金之外，其它资源以及行 业绩效等方面不存在显著差异。

Translated and revised from Guanli Shijie 管理世界 (Management World), 2007, (3): 130-137

LI Shanmin

School of Business, Sun Yat-sen University, Guangzhou 510275, China

E-mail: mnslsm@mail.sysu.edu.cn,

ZHOU Xiaochun $(\bowtie)$

College of Economics and Management, South China Agricultural University, Guangzhou 510642, China

E-mail: Luckyzoezhou@yahoo.com.cn 
关键词 公司绩效, 行业绩效, 并购类型, 多元化并购

\section{Introduction}

From the 1960s to middle 1980s, diversification strategies were preferred by many Western firms. However, since the 1990s, a lot of firms in developed countries have gradually shifted back to refocusing strategy. Those firms still sticking to diversification have also focused more on related acquisition. In China, however, things are quite different. Although under the planned economy, Chinese firms tended to be involved in a wide range of different businesses concurrently (e.g., from processing industries to retail and trading, even to running schools or hospitals, etc.), it was not diversification in the strict sense. Since the 1990s, with the formal establishment of China's market economy, an increasing number of Chinese firms have chosen to adopt diversification strategy. Till 2005, about $2 / 3$ of the listed firms implemented diversification strategies and the number is increasing (Jiang, 2006). There are two ways to realize diversification. One is to expand new businesses or enter an industry by firm's own effort. The other is by conducting unrelated acquisition. The latter was especially preferred by firms owning to its lower cost and higher rate of success. In addition, acquisition also facilitates a firm's quick entry into some industries featured with strict government control, high technology threshold and lucrative short-term profits. With the intensification of China's market-oriented economic reform, it has been easier for Chinese firms to conduct acquisition activities in a capital market. As a result, more Chinese firms have chosen acquisition as an effective means of diversification. Such phenomenon has naturally drawn attention from researchers and practitioners alike.

Extant Western studies on diversification literature have stressed the effect of unrelated acquisition on firm value and a lot of inconsistent conclusions have been drawn. Among them, Elgers and Clark (1980) studied acquisition cases happened from 1957 to 1975 and found that shareholders (both in the acquiring firm and the acquired firm) gain more benefits from related acquisitions than from unrelated ones. However, the conclusion was not supported statistically. Lubatkin (1987) took the acquisitions happened from 1948 to 1979 as sample and found that the acquisition tend to bring about significant and positive abnormal returns to shareholders of both sides, regardless of the types of acquisition. In a study of 105 big acquisition cases occurred from 1975 to 1979, Singh and Montgomery (1984) found that shareholders in the acquired firm gain more benefits in related acquisitions than that of in unrelated ones, yet the benefits of shareholders in the acquiring firms remain unchanged in both cases. Based on a sample of 765 
acquisition events from 1955 to 1987, Agrawal et al. (1992) argued that both related and unrelated acquisition lead to negative long-term abnormal returns within five years after the acquisition. In the contrary, the loss of unrelated acquisition case is smaller than that of in related acquisition case.

Likewise, Gregory (1997) studied 452 acquisition cases from 1984 to 1992 and found that the abnormal returns gained from unrelated acquisition tend to be negative, but loss caused by unrelated acquisition is substantially smaller than that of in related acquisition. Berger and Ofek's (1999) study showed that refocusing brings significant and positive abnormal returns to the acquiring firm, proving indirectly the inefficiency of diversification-oriented acquisition.

However, there has been little empirical study concentrating on unrelated acquisition in China. Li and Zhu (2006) found empirically that unrelated acquisition conducted by Chinese listed firms fail to create value for these firms. Domestic research in this area has concentrated on the effects of industrial relevance in acquisition cases on firm value and, no consistent conclusion has been drawn to date. Feng and $\mathrm{Wu}$ (2001) found that different acquisition type would have different post-acquisition effects on firm performance. They concluded that firm performance in conglomerate merger and horizontal merger tend to be better than that of in vertical merger. Li and Chen (2002) found that shareholders in the acquiring firm can obtain considerable benefits from related acquisition while in unrelated acquisition cases, things are different. Li et al. (2004) also found that related acquisition is advantageous for performance improvement in the same year of the merger whereas this promoting effect disappears for other years.

Why related acquisition would create more value than unrelated acquisition? Are there any differences in firms and industry characteristics between firms conducting related acquisition and firms conducting unrelated acquisition? To our best knowledge, only several Western scholars have noticed the impact of pre-acquisition firm characteristics on types of diversification. Park (2003) studied over 10 million acquisition cases happened during the period of 1974-1979. He found that the performance of firms conducting related acquisitions tend to be better than the performance of firms conducting unrelated acquisitions. Based on diversification data from 1981 to 1985, Chatterjee and Wernerfelt (1991) pointed out that firms pursuing related diversification tend to have more physical resources, knowledge resources and external financial resources, while firms pursuing unrelated diversification usually have sufficient internal funds. Other studies (e.g., Bettis and Hall, 1982; Christensen and Montgomery, 1981) emphasize the effect of pre-acquisition industry performance of types of diversification-oriented acquisition. For example, Bettis and Hall (1982) argued that theoretically, firms in high-profit industries are more likely to 
pursue related diversification, while firms in low-profit industries would prefer unrelated diversification. However, they did not support this argument with empirical evidence.

To sum up, there has been limited research studying comprehensively the influences of firm characteristics, industry characteristics and strategy types prior to acquisition. Domestic study on the relationship between firm characteristics and types of acquisition is also scarce. This study aims to explore the relationship among firm characteristics, industry characteristics and acquisition types in China. As China's economy is still in a transitional period, a firm's decision making is inevitably affected by the macro institutional environment. We take major acquisition events from 2001 to 2004 as sample and explore the impact of firm and industry characteristics of the acquiring firms on the later acquisition strategy prior to the execution of acquisition. In doing so, we hope to identify the differences between firms conducting unrelated acquisition and firms conducting related acquisition and gain a deeper understanding of the relationships among firm performance, industry performance and acquisition strategies.

\section{Theories and hypotheses}

\subsection{Firm characteristics and acquisition strategy}

\subsubsection{Prospect theory and firm performance}

A firm's performance influences its motive for diversification and choice of specific diversification strategy. Whether to pursue related or unrelated acquisition is, however, related to a firm's performance and its risk preference. The prospect theory suggests that individuals under more favorable conditions are more risk averse whereas individuals under unfavorable situations are more risk seeking (Kahneman and Tversky, 1979). Top managers in high-profit firms (favorable conditions) are thus more risk averse than those in low-profit firms (unfavorable conditions). According to the prospect theory, all decisions are made by top managers under uncertainty. Decision makers thus need to acquire sufficient knowledge and skills to make more accurate decisions. Managers conducting related acquisition tend to know more about the product, market, technology and industry of the acquired business than managers conducting unrelated acquisition. We can thus infer, based on the prospect theory, there is less risk in related acquisition than that in unrelated acquisition (Sitkin and Pablo, 1992). Therefore, managers in high-profit firms might prefer related acquisition to unrelated one, contrary to managers in lower profit firms. We thus hypothesize that:

H1 Firms with better performance prior to acquisition are more likely to pursue related acquisition rather than unrelated acquisition. 


\subsubsection{Resource-based view and available resources}

The resource-based view argues that firm resources are heterogeneous and these heterogeneous resources bring sustainable competitiveness for firms, resulting in varied performance among different industries. Resource transfer has proved to be difficult due to high cost or other obstructive factors, such as technology confidentiality, technology complexity and resource interoperability, etc. Therefore, a firm pursuing diversification is mainly attributed to two reasons: First, it wants to utilize its abundant strategic resources by means of entering into those product markets in which these resources can bring forth competitiveness. Second, it wants to acquire another firm's heterogeneous resources. Resources vary with their scarcity and liquidity.

Teece (1981) identified three classes of resources, namely physical resources, intangible assets, and financial resources. Physical resources mainly refer to tangible assets such as plant and equipment. They are applicable only for related acquisition; Intangible assets refer to knowledge, skills and brand names, etc. Similar to physical resources, intangible assets are more favorable for related acquisition. Financial resources include internal and external funds. As a rule, firms with abundant internal funds incline to pursing unrelated diversification so that they can obtain the physical assets and intangible assets (such as knowledge) from the acquired firm immediately. External funds mainly originated from rationed or newly issued shares. When acquisition is executed in the form of share acquisition, firms have easier access to external funds are more likely to conduct related acquisition. We thus hypothesize that:

H2 Firms with abundant physical knowledge and external funds resources prior to acquisition are more likely to conduct related acquisition, while firms with abundant internal funds are more likely to conduct unrelated acquisition.

\subsubsection{Agency theory and business risk}

It has been proposed that firms conduct acquisition to reduce business risk (Amihud and Lev, 1981). In agency theory, the two parties in the agency relationship (i.e. the manager and the shareholder) are assumed to maximize their own utilities. It is thus assumed that the agent/manager does not always act in the best interests of the principal/shareholders, particularly when their interests are conflicting (Jensen and Meckling, 1976). In general, unrelated acquisition, through diversification effects, leads to reduced risk for the combined entity. In efficient capital markets, such risk reduction can not be beneficial to shareholders since they can achieve on their own the desired level of risk through portfolio diversification. Managers, however, cannot diversify their employment risk (e.g., 
risk of losing job, professional reputation, etc.) in capital markets. Therefore, managers tend to pursue unrelated acquisition to reduce their undiversifiable employment risk (Amihud and Lev, 1981). This situation is very common in China. As most of Chinese listed firms are state-controlled, those firms' managers are appointed by government, so they do not hold any stock of their managed firms. According to the agency theory, managers may prefer to undertake actions that maximize their personal utility. The goal for these government-appointed managers is to climb political ladder rather than for the maximization of shareholders' interest. Therefore, managers wish the firms they are currently managing could be operated steadily and safely. In doing so, they have strong motives for reducing their career risks by pursing diversification. Since appointment of agents tends to occur in firms with high pre-acquisition risks, it seems reasonable to assume that:

H3 Prior to acquisition, the higher business risk a firm faces, the more likely it adopts unrelated acquisition strategy.

\subsubsection{Institutional factors and ownership structure}

As China's economy is still in a transitional period, when studying the diversification of Chinese listed firms, one shall take into consideration China's macro institutional environment. The institutional theory argues that the institutional features under a transitional economy are one of the important determinants of firm behaviors and their diversification. Generally speaking, all transitional economies are characterized by less-developed market mechanisms and lower market efficiency. Direct government interference or social network may sometimes even replace market mechanism in allocating resources. As a result, firms in transitional economies or newly-merged market economies depend, to a large extent, on non-market resource allocation mechanism (such as government control or social network) to obtain needed resources (Khanna and Palepu, 2000). Since resources allocated through non-market mechanisms are usual general-purpose resources (such as capital or talents) which can be used to support all types of business modes. Thus to best utilize these general-purpose resources, a firm will choose to reinvest in different industries or product markets, giving rise to the emergence of many highly diversified firms. Since government is still in control of some key resources, the quality of the relationship between government and firms becomes a key determinant of a firm's degree of diversification. Khanna and Palepu (2000) found that in South Korea and India, firms obtain support from government in a number of ways, such as authorization, policy support, or even direct government, which improve in turn these firms' degrees of diversification. Considering the importance of 
government influence on firms, we develop $\mathrm{H} 4$ as follows:

H4 The higher the proportion of state shares in a firm prior to acqusition, the more likely it to choose unrelated acquisition.

\subsection{Industry characteristics and acquisition strategy}

A firm's choice of related or unrelated acquisition is also affected by the characteristics of the industry it is in (Christensen and Montgomery, 1981). When an industry has poor performance and is thus regarded as unpromising, firms in the industry are more likely to engage in aggressive acquisition, which means that firms attempt to avoid adverse impact from the old industry by entering into new and more attractive industries through acquisition. Ansoff (1965) proposed that firms should execute diversification to solve problems they faced in the old industry, such as market saturation, decline in demand, competition pressures, and product-line obsolescence, etc. He also pointed out that when reinvestment in an old industry brings only skinny profit margin or there is few opportunity in the industry, firms should adopt diversification strategies. Under such circumstances, continuing to stay in the old business will only make things worse (Christensen and Montgomery, 1981), thus firms in industries with low performance are more inclined to seek more opportunities for unrelated acquisition.

However, as an industry's performance increases, top managers of firms in the industry will have stronger motives for defensive acquisition, while their motives for aggressive acquisition decrease. Defensive acquisition refers to a better utilization of present resources and capabilities so as to ensure a better firm development in the current industry. Industry average performance is a key indicator of the attractiveness of an industry. Firms in high-profit industries tend to have strong motives to continue staying in their present industries by strengthening themselves through related acquisition, while firms in low-profit industries have to rely on unrelated acquisition in their attempts to enter high-profit industries. Therefore, we develop the last hypothesis as follows:

H5 Firms conducting related acquisition are more likely to come from high-profit industries, while firms conducting unrelated acquisition are more likely to come from low-profit industries.

\section{Methods}

\subsection{Sample}


Acquisition in this paper refers to a firm (the acquiring firm) obtains the property rights and control rights of another firm (the acquired firm) through share or asset acquisition, for the purpose of its fast expansion. The classification of industries is conducted according to the Guidelines for Classification of Listed Companies (the Guidelines) issued by China Securities Regulatory Commission. Since the Guidelines were officially issued in 2001, we chose the period of 2001 to 2004 as the time interval. All acquisition data were obtained from the China Listed Companies' Merger \& Acquisition, Asset Restructuring Research Database (2004) in the databank of China Stock Market \& Accounting Research (CSMAR) co-developed and maintained by the Center for China Financial Research at the University of Hong Kong and the Shenzhen GTA Information Technology Co. Financial and other data were also obtained from CSMAR and the databank of China Securities Journal. When the industry code of the acquired firm is the same as that of the acquiring firm, the acquisition is regarded as related acquisition. When the industry code of the acquired firm is not the same as that of the acquiring firm and the industry the acquired firm is in does not belong to high-profit industry (i.e. with more than $10 \%$ profit margin), the acquisition is deemed as unrelated acquisition. In addition, we select acquisition cases based on the following criteria: (1) The declare time of acquisition can be obtained. (2) The acquiring firm is a listed public companies, and the industry of the acquired firm is in can be affirmed by the Guidelines. (3) Assets acquired worth more than 10 million RMB Yuan. (4) Acquiring firms neither come from the finance industry nor from the comprehensive industry. (5) The acquiring firms did not include those firms that conducted both related and unrelated acquisitions during 2001 to 2004 .

After the above screening and elimination of observations with incomplete data, a total of 317 acquisition cases, including 148 related acquisition and 169 unrelated ones. The annual distribution of samples is shown in Table 1.

Table 1 Annual distribution of samples

\begin{tabular}{lccccc}
\hline & 2001 & 2002 & 2003 & 2004 & Total \\
\hline Related acquisitions & 20 & 36 & 48 & 44 & 148 \\
Unrelated acquisitions & 31 & 35 & 52 & 51 & 169 \\
\hline
\end{tabular}

In addition, we divide all the sampled acquisition cases by industry as stipulated in the Guidelines. As shown in Table 2, acquisitions occur mainly in certain industries. Specifically, most of the acquired firms are either in industries characterized by government-regulated (e.g., finance, insurance, electric power, gas and water supply, etc.), high technology barrier (e.g., machinery, equipments, industrial instrument manufacturing, medicine, biological products, etc.), or 
industries characterized by low entry barrier but high short-term profit (e.g., real estate). In comparison, most of the acquiring firms are from traditionally high risk industries such as wholesales, retail trade, agriculture, forestry, animal husbandry, fisheries and water conservancy, etc.

Table 2 Samples distribution by industry

\begin{tabular}{|c|c|c|c|c|c|c|c|}
\hline \multirow[t]{2}{*}{$\begin{array}{l}\text { Industry } \\
\text { code }\end{array}$} & $\begin{array}{l}\text { Related } \\
\text { acquisi- } \\
\text { tion }\end{array}$ & $\begin{array}{l}\text { Unrelated } \\
\text { acquisi- } \\
\text { tion }\end{array}$ & $\begin{array}{l}\text { Unrelated } \\
\text { acquisi- } \\
\text { tion }\end{array}$ & \multirow[t]{2}{*}{$\begin{array}{c}\text { Industry } \\
\text { code }\end{array}$} & $\begin{array}{l}\text { Related } \\
\text { acquisi- } \\
\text { tion }\end{array}$ & $\begin{array}{l}\text { Unrelated } \\
\text { acquisi- } \\
\text { tion }\end{array}$ & $\begin{array}{l}\text { Unrelated } \\
\text { acquisi- } \\
\text { tion }\end{array}$ \\
\hline & $\begin{array}{l}\text { The acqui- } \\
\text { ring }\end{array}$ & $\begin{array}{l}\text { The acqui- } \\
\text { ring }\end{array}$ & $\begin{array}{l}\text { The acqui- } \\
\text { red }\end{array}$ & & $\begin{array}{l}\text { The acqui- } \\
\text { ring }\end{array}$ & $\begin{array}{l}\text { The acqui- } \\
\text { ring }\end{array}$ & $\begin{array}{l}\text { The acqui- } \\
\text { red }\end{array}$ \\
\hline A & 1 & 12 & 1 & D & 9 & 10 & 13 \\
\hline B & 6 & 3 & 2 & E & 0 & 5 & 4 \\
\hline $\mathrm{C} 0$ & 5 & 7 & 9 & $\mathrm{~F}$ & 5 & 2 & 2 \\
\hline $\mathrm{C} 1$ & 7 & 10 & 1 & G & 9 & 12 & 11 \\
\hline C3 & 3 & 3 & 2 & $\mathrm{H}$ & 5 & 22 & 5 \\
\hline $\mathrm{C} 4$ & 17 & 14 & 5 & I & - & - & 17 \\
\hline $\mathrm{C} 5$ & 8 & 5 & 4 & $\mathrm{~J}$ & 14 & 6 & 42 \\
\hline C6 & 16 & 11 & 10 & K & 3 & 8 & 8 \\
\hline C7 & 23 & 24 & 13 & $\mathrm{~L}$ & 3 & 1 & 2 \\
\hline C8 & 13 & 10 & 18 & & & & \\
\hline C99 & 1 & 4 & 1 & Total & 148 & 169 & 169 \\
\hline
\end{tabular}

\subsection{Variables}

\subsubsection{Dependent variable: Acquisition strategy}

As a dependent variable, acquisition strategy is represented by a dummy variable. If an acquisition is categorized as a "related acquisition", the variable "related acquisition" equals "l". If an acquisition is classified as an "unrelated acquisition", the variable "related acquisition" equals " 0 ".

\subsubsection{Independent variables}

Pre-acquisition firm performance. A firm's re-acquisition performance is represented by three variables: returns on assets (ROA), returns on equity (ROE), and earnings per share (EPS). Given that some sampled firms had negative net assets, we use ROA and EPS as indicators of a firm's financial performance. Pre-acquisition financial performance is measured with 3-year average ROA and EPS, including the year when the acquisition happened and 2 preceding years 
(abbreviated as FROA and FEPS, respectively).

Pre-acquisition industry performance. An industry's pre-acquisition financial performance is represented by 3-year average ROE or EPS in the industry, including the year when the acquisition happened and 2 preceding years (abbreviated as IROA and IEPS, respectively). Industries are divided in accordance with the Guidelines, that is, firms with identical first 3-digit SIC code are regarded as in the same industry.

Pre-acquisition available resources. As above, pre-acquisition available resources can be categorized into three subtypes, namely physical resources, intangible assets, and financial resources. We use the fixed assets of a firm to its total assets in the previous pre-acquisition fiscal year to denote its available physical resources (abbreviated as FOA). Available intangible assets are represented by a firm's intangible assets to its total assets in the previous pre-acquisition fiscal year (abbreviated as IOA). Financial resources consist of internal and external funds. The former is measured by three indexes, namely leverage (defined as a firm's long-term debt in the previous fiscal year to its total assets), current ratio (defined as the current assets to current liabilities), and undistributed profit per share in the previous pre- acquisition fiscal year (abbreviated as UNDP); the latter is measured by a firm's total net amount of capital raised through newly issued and rationed shares prior to the announcement of acquisition divided by the firm's total assets (abbreviated as AAcap).

Pre-acquisition risk. A firm's pre-acquisition risk is measured from the perspective of accounting risks. The fluctuation of annual ROA or EPS of a firm since the year it became listed to the previous year of the acquisition (abbreviated as RiskROA and RiskEPS, respectively) is used to indicate the firm's business risk. For firms become listed for less than three years, the data in the years before its listing will be used to calculate the fluctuation of its ROA or EPS.

Pre-acquisition ownership structure. The exploration of ownership structure is aimed at gaining a deeper understanding of the relationship between Chinese listed firms and government. It is generally believed that state-owned enterprises in transitional economics have easier access to some special resources. In this study, we use the ratio of state shares (including state-owned legal-person shares) in the previous fiscal year of acquisition to total shares in a firm (SOE) and the nature of a firm's ultimate controller (SC, 1 stands for government as the ultimate controller, 0 stands for natural persons or worker's union as the ultimate controller) as proxies for pre-acquisition ownership structure.

\subsubsection{Control variables}

Pre-acquisition firm size. Chatterjee and Wernerfelt (1991) speculated that firm 
size might be positively related to unrelated acquisition while Wiersema and Bantel (1992) expected firm size to be negatively related to unrelated acquisition. Therefore, we need to control the effects of firm size. This paper uses the natural logarithm of the acquiring firm's total assets one year prior to its each acquisition (Log (Assets)) as an indicator of pre-acquisition firm size.

Listed years. It is generally accepted that the longer time a firm becomes listed, the more resources it accumulates, the more developed the industry the firm is in, and the more likely the firm is to pursue external development. We thus need to control the effect a firm's listing years on its motive for acquisition. The natural logarithm of the acquiring firm's listed years ( $\log ($ ListY)) is used to control this effect.

Pre-acquisition diversification profile. Amburgey and Miner (1992) argued that a firm tends to pursue strategic actions that are the same as or the expanded version of the firm's previous strategies. Therefore, if a firm has pursued largely related (unrelated) diversified projects over time, and thus its overall diversification profile is a related (unrelated) one, the firm is more likely to continue pursuing related (unrelated) acquisition over unrelated (related) acquisition. Diversification profile in this paper is defined as the rate of main operational sales and profits: If the rate of prime operational revenues and profits are all over $90 \%$, then the firm is regarded as concentrated on one industry, so the diversification profile is coded as " 1 ". If a firm's operational revenues and profits from another industry exceed $10 \%$, the firm is regarded as running businesses in 2 industries concurrently. Adding up the number of industries that the firm have business in, we get the diversification profile of the firm. For example, Sichuan He Jia Co. Ltd. (600093) announced its diversified operation in 5 industries in its annul report in 2003. However, there were only 4 industries' sales and profits exceeded $10 \%$, and the sales and profits of its foods sector were all less than $1 \%$, we then define that the diversification profile of the firm as " 4 ".

Time of acquisition. Since the acquisition cases sample in this paper occurred in 2001-2004, the data are characterized by inter-temporal features. Thus we use a dummy variable (Year Dum) to eliminate the time effects. Concretely, if an acquisition occurs at a certain year, then the very year is coded as "1", all other years are coded as " 0 ".

\section{Results}

\subsection{Statistical description of the sample}

Since we assume that related and unrelated acquisition samples may demonstrate different characteristics, we first conduct t-test on the characteristic variables of the two types of samples. Then non-parameter tests on the variable medians are executed. The results are shown in Table 3. 
Table 3 Comparison of the characteristic indexes between related and unrelated acquisitions

\begin{tabular}{|c|c|c|c|c|c|c|}
\hline \multirow[b]{2}{*}{ Variables } & \multicolumn{3}{|c|}{ Average } & \multicolumn{3}{|c|}{ Median } \\
\hline & $\begin{array}{c}\text { Related } \\
\text { acqui- } \\
\text { sition }\end{array}$ & $\begin{array}{l}\text { Unrelated } \\
\text { acquisi- } \\
\text { tion }\end{array}$ & $\begin{array}{c}\text { T-test } \\
\text { value }\end{array}$ & $\begin{array}{l}\text { Related } \\
\text { acquisi- } \\
\text { tion }\end{array}$ & $\begin{array}{l}\text { Unrelated } \\
\text { acquisi- } \\
\text { tion }\end{array}$ & $\begin{array}{l}\text { Kruskal-Wallisy } \\
\text { test value }\end{array}$ \\
\hline$\overline{R O A}$ & 0.039 & 0.014 & $3.040^{* * *}$ & 0.038 & 0.025 & $16.670^{* * * *}$ \\
\hline$E P S$ & 0.243 & 0.102 & $3.717^{* * *}$ & 0.234 & 0.151 & $19.979^{* * *}$ \\
\hline IROA & 0.023 & 0.020 & 0.634 & 0.022 & 0.024 & 0.116 \\
\hline IEPS & 0.162 & 0.152 & 1.146 & 0.146 & 0.138 & 1.745 \\
\hline Current & 2.005 & 1.944 & 0.220 & 1.549 & 1.408 & 2.472 \\
\hline Leverage & 0.084 & 0.062 & 1.506 & 0.049 & 0.029 & $7.802^{* * *}$ \\
\hline$U N D P$ & 0.228 & 0.190 & 0.721 & 0.186 & 0.229 & 0.005 \\
\hline AAcap & 0.121 & 0.112 & 0.480 & 0.085 & 0.066 & 0.485 \\
\hline FOA & 0.325 & 0.302 & 1.154 & 0.287 & 0.285 & 0.811 \\
\hline$I O A$ & 0.038 & 0.049 & 1.400 & 0.016 & 0.028 & $8.906^{* * *}$ \\
\hline RiskROA & 0.029 & 0.039 & $2.574^{* * *}$ & 0.021 & 0.026 & $7.898^{* * *}$ \\
\hline RiskEPS & 0.123 & 0.151 & $2.164^{* *}$ & 0.080 & 0.109 & $5.372^{* *}$ \\
\hline$S O E$ & 44.361 & 33.477 & $4.228^{* * *}$ & 50.140 & 32.870 & $17.756^{* * *}$ \\
\hline$I N D$ & 1.588 & 2.172 & $5.644^{* * *}$ & 1.000 & 2.000 & $38.571^{* * *}$ \\
\hline
\end{tabular}

Note: ${ }^{*}$ indicates $p<0.1 ;{ }^{* *}$ indicates $p<0.05 ;{ }^{* * *}$ indicates $p<0.01$, the same in tables below.

As shown in Table 3, we could find that: (1) The average and median of pre-acquisition firm performance in firms pursuing related acquisition are significantly better than that of in firms pursuing unrelated acquisition. This finding supports H1. (2) There is significant difference in pre-acquisition business risks between related acquisition and unrelated acquisition firms, and the business risk of the former is higher than the latter. This finding supports preliminarily H3. (3) We find no significant difference in available resources and industry performance between unrelated acquisition firms and related acquisition firms. (4) There is significant difference in diversification profile a year prior to acquisition between the two types of firms. Firms executed diversification strategies tend to prefer unrelated acquisition to related ones. (5) The ratio of state shares in unrelated acquisition firms is significantly different (lower) than that of in related acquisition firms, which is inconsistent with H4. Possible explanation maybe that most firms pursuing related acquisition are in specially protected industries not open to outsiders. As a result, these industries are monopolized by big state- owned enterprises with high ratio of state shares.

In sum, Table 3 demonstrates that there are significant differences in pre- 
acquisition firm performance, risk and ratio of state shares between related and unrelated acquisition firms. Yet further studies are needed as to how these differences influence a firm's acquisition strategy.

\subsection{Regression analysis}

\subsubsection{Logistic regression analysis}

As the dependent variable (acquisition strategy) is a dummy variable, we adopt the Logistic regression analysis to test relevant hypotheses. The empirical results are presented in Table 4.

Table 4 Results of Logistic regression analysis

\begin{tabular}{|c|c|c|c|c|c|}
\hline & \multirow{2}{*}{$\begin{array}{c}\text { Independent } \\
\text { variable }\end{array}$} & \multicolumn{2}{|c|}{ Model 1} & \multicolumn{2}{|c|}{ Model 2} \\
\hline & & Coefficient & $z$-test value & Coefficient & $z$-test value \\
\hline & Constant & -12.978 & $-3.048^{* * *}$ & -13.632 & $-3.295^{* * *}$ \\
\hline \multirow{2}{*}{$\begin{array}{l}\text { Firm perfor- } \\
\text { mance }\end{array}$} & FROA & 13.466 & $3.164^{* * *}$ & & \\
\hline & FEPS & & & 3.364 & $3.450^{* * *}$ \\
\hline \multirow{2}{*}{$\begin{array}{l}\text { Industry perfor- } \\
\text { mance }\end{array}$} & IROA & 0.536 & 0.147 & & \\
\hline & IEPS & & & 0.302 & 0.162 \\
\hline \multirow{6}{*}{$\begin{array}{l}\text { Firm available } \\
\text { resources }\end{array}$} & $F O A$ & -0.681 & -0.854 & -0.510 & -0.627 \\
\hline & $I O A$ & -0.097 & -0.048 & -0.409 & -0.211 \\
\hline & Current & 0.009 & 0.144 & 0.005 & 0.074 \\
\hline & Leverage & 1.198 & 1.217 & 1.329 & 1.319 \\
\hline & $U N D P$ & -1.004 & $-2.424^{* *}$ & -1.218 & $-2.864^{* * *}$ \\
\hline & AAcap & 1.593 & $1.776^{*}$ & 1.324 & 1.522 \\
\hline \multirow[t]{2}{*}{ Firm risk } & RiskROA & -9.217 & $-1.851^{*}$ & & \\
\hline & RiskEPS & & & -2.224 & -1.539 \\
\hline $\begin{array}{l}\text { State stockh- } \\
\text { oldings }\end{array}$ & SOE & 0.012 & $2.025^{* *}$ & 0.014 & $2.327^{* *}$ \\
\hline \multirow{5}{*}{$\begin{array}{l}\text { Control } \\
\text { variables }\end{array}$} & $I N D$ & -0.616 & $-4.133^{* * *}$ & -0.564 & $-3.751^{* * *}$ \\
\hline & $\log ($ Assets $)$ & 0.662 & $3.256^{* * *}$ & 0.667 & $3.301^{* * *}$ \\
\hline & $\log (\operatorname{List} Y)$ & -0.128 & -0.532 & 0.006 & 0.023 \\
\hline & LR-test Value & \multicolumn{2}{|c|}{77.023} & \multicolumn{2}{|c|}{81.353} \\
\hline & McFadden $R^{2}$ & \multicolumn{2}{|c|}{0.176} & \multicolumn{2}{|c|}{0.186} \\
\hline
\end{tabular}

Note: The time of acquisition is also a control variable in the Logistic regression analysis. However, it is not listed in the above table due to its statistical insignificance.

The results in Table 4 indicate that there is significant and positive relationship between pre-acquisition firm performance (Both ROA and EPS) and related acquisition. This indicates that the better financial performance a firm has, the 
more likely it is to pursue related acquisition. These findings strongly support $\mathrm{H} 1$ $(p<0.01)$. These results tell us that when studying the relationship between unrelated acquisition and firm performance, we shall pay more attention to the causality between the two (Hall, 1995). In other words, sometimes the reason why unrelated acquisitions fail to improve firm performance may relate with a firm's pre-acquisition performance.

However, though Model 1 and 2 show that the better industry performance a acquiring firm is in, the more likely the firm to pursuing related acquisition, the results are not statistically significant. H5 is not supported. Then why Chinese firms in high-profit industries still pursue diversification? We think this phenomenon may have something to do with China's exterior economic environments from 2001 to 2004. To demonstrate, we take the real estate industry as an example. In China, real estate industry has been the most favored target industry for unrelated acquisition (about 25\% unrelated acquisition sample firms entered this industry from 2001 to 2004). Ever since the start-up of reform and opening up policy in 1978, China's real estate industry has witnessed dramatic development. Meanwhile, real estate industry is characterized by low entry barrier, high profit and easy withdrawal. As a result, firms with abundant capital are eager to enter the industry to get a slice of the cake. This can be proved by the significant and negative relationship between UNDP and related acquisition in Table 4.

In $\mathrm{H} 2$, we suppose that firms with abundant physical resources, intangible assets and external funds are more likely to pursue related acquisition, while firms with plentiful internal funds tend to favor unrelated acquisition. However, Table 4 shows that abundant internal funds are more likely to lead to unrelated acquisition and the others available resources do not significantly related to related acquisitions (external funds positively related to related acquisition only at 0.1 significance level). Thus $\mathrm{H} 2$ was only partially supported. Furthermore, as shown in Table 4, pre-acquisition risk is positively related to unrelated acquisition, showing the higher business risk a firm faces, the more likely it is to pursue unrelated acquisition. So H3 is supported. Finally, there is a high ratio of stare shares in related acquisition firms. Thus both Table 3 and 4 all deny H4. Jin and $\mathrm{Yu}(2005)$ argued that firms with over 50\% state shares are likely to engage in diversification for they need to extra job positions to resettle redundant employees, which is a tradition for Chinese state-owned companies. To further test the relationship between state-owned holding and acquisition type, we add the dummy variable of $S C$ to designate whether a firm is state owned. As the results shown, there is no significant relationship between a firm's ownership and its diversification, supporting to a certain extent our assumption that higher ratio of state share does not necessarily lead to unrelated acquisition. 
As for the three control variables, the results show that a firm's pre-acquisition diversification profile is significantly and negatively related to its choice of related acquisition over unrelated acquisition $(p<0.01)$. That is, if a firm is largely engaged in unrelated diversification over time, and thus its diversification profile is an unrelated one, the firm is less likely to pursue related acquisition over unrelated acquisition (Amburgey and Miner, 1992). These results are also consistent with the assumption that the pre-acquisition size of an acquiring firm is positively related to its tendency to pursue related acquisition over unrelated acquisition $(p<0.01)$ (Park, 2003). However, the results do not support the assumption that the pre-acquisition listed years of an acquiring firm is positively related to a firm's tendency to pursue unrelated acquisition over related acquisition, showing that pre-acquisition listed time does not affect a firm's acquisition strategy.

\subsubsection{Fitness prediction test}

To test the prediction capability of the above models (Model 1 and Model 2 in Table 4), this paper uses " $46.6877 \%$ " (which is the percent of related acquisition to total samples) as a probability threshold to do fitness prediction test (as shown in Table 5).

Table 5 Results of fitness prediction test

\begin{tabular}{|c|c|c|c|c|c|c|}
\hline & \multicolumn{3}{|c|}{ Model $1(R O A)$} & \multicolumn{3}{|c|}{ Model 2 (EPS) } \\
\hline & \multicolumn{3}{|c|}{ Prediction: related acquisitions } & \multicolumn{3}{|c|}{ Prediction: related acquisitions } \\
\hline & $\begin{array}{c}\text { Related } \\
\text { acqui- } \\
\text { sitions }\end{array}$ & $\begin{array}{l}\text { Unrelated } \\
\text { acquisi- } \\
\text { tions }\end{array}$ & $\begin{array}{c}\text { Accuracy } \\
(\%)\end{array}$ & $\begin{array}{l}\text { Related } \\
\text { acqui- } \\
\text { sitions }\end{array}$ & $\begin{array}{l}\text { Unrelated } \\
\text { acquisi- } \\
\text { tions }\end{array}$ & $\begin{array}{c}\text { Accuracy } \\
(\%)\end{array}$ \\
\hline $\begin{array}{l}\text { Related } \\
\text { acquisitions }\end{array}$ & 109 & 39 & 73.65 & 109 & 39 & 73.65 \\
\hline $\begin{array}{l}\text { Unrelated } \\
\text { acquisitions }\end{array}$ & 47 & 121 & 72.02 & 48 & 120 & 71.43 \\
\hline Total accuracy & Threshol & 0.466877 & 72.78 & Threshol & : 0.466877 & 72.47 \\
\hline
\end{tabular}

The results shown in Table 5 indicate that the total prediction accuracy of Model 1(using ROA to signify performance) is $72.78 \%$. In testing how many firms want to conduct related acquisition in the 148 related acquisition firms, Model 1 predicts that there are 109 firms would execute related acquisitions, and its prediction accuracy for related acquisition is $73.65 \%$. In testing how many firms want to conduct unrelated acquisitions in the 168 unrelated acquisitions firms, Model 1 predicts that there are 122 firms would execute unrelated acquisitions, and its prediction accuracy for unrelated acquisition is $72.02 \%$. 
Likewise, the total prediction accuracy of Model 2(using EPS to signify performance) is $72.47 \%$. Its prediction accuracy for related acquisition and unrelated acquisition are $73.65 \%$ and $71.43 \%$, respectively. Judging by the total prediction accuracy of the two models, we could conclude that they can distinguish satisfactorily different characteristics between related and unrelated acquisitions.

\section{Discussion and Conclusions}

Taking 148 related acquisitions and 169 unrelated acquisitions cases of Chinese listed firms happened in the year of 2001-2004 as sample, this paper studies the pre-acquisition firm and industry characteristics. Results show that there are significant differences between related acquisition firms and unrelated acquisition ones: (1) The pre-acquisition firm performance in related acquisition firms tends to be better than that of in unrelated acquisition firms. (2) The pre-acquisition size of related acquisition firms tend to be bigger than unrelated acquisition firms. (3) The pre-acquisition diversification profile has great impact on a firm's later choice of acquisition type. Formerly specialized firms tend to pursue related acquisition while diversified firms tend to pursue unrelated acquisition. (4) Although Chinese state-owned listed firms have easier access to government resources, they are always in monopolized industries or industries with high entry barrier. To maintain their advantageous positions, these firms incline to conduct related acquisition to further strengthen their positions in the industry.

Park (2003) found that the pre-acquisition industry performance is an important factor influencing firm's diversification strategy. Although in this paper, we find little difference in pre-acquisition industry performance between related acquisitions firms and unrelated acquisitions firms, but these findings are supported in statistical and in regressions analyses. We also find that higher pre-acquisition state share ratio does not necessarily lead to diversification.

As above, the diversification-oriented acquisition in China has its distinctive characteristics. Inconsistent with Park's (2003) conclusion, we find that although there are some differences in the industries of related and unrelated acquisition firms, these differences exert little impact on the choice of acquisition strategy. We also find that high pre-acquisition state share ratio does not necessarily lead to diversification. We believe this phenomenon has something to do with China's unique institutional environment: Firms with largest state shares ratios are always in strictly regulated and highly monopolized industries, resulting in abnormal returns in these industries. In order to keep enjoying the high profit, state-owned 
enterprises are more enthusiastic about strengthening their position in their industries by conducting related acquisition.

We also find that related acquisition seems to be better at bringing forth higher profit than unrelated acquisition, which is not because relation acquisition is superior to unrelated acquisition to a certain degree, but due to that firms pursuing related acquisition usually have more advantages (such as financial performance, performance, etc.) over firms pursuing unrelated acquisition. Thus we suggest when studying the relation between diversification and firm performance, more attention should be drawn to the causality relation between diversification and firm performance. In addition, pre-acquisition firm performance shall be controlled when studying the effect of diversification on firm performance. A firm's pre-acquisition diversification profile also has effects on the firm's choice of acquisition type. These two points are both the suggestions and direction for further study.

Acknowledgements This paper is supported by the National Natural Science Foundation of China (No. 70572054) and the Natural Science Foundation of Guangdong (No. 05003278).

\section{References}

Agrawal A, Jaffe J F, Mandelker G N (1992). The Post-merger performance of acquiring firms: A re-examination of an anomaly. Journal of Finance, 47: 1605-1621

Amburgey T L, Miner A S (1992). Strategic momentum: The effects of repetitive, positional, and contextual momentum on merger activity. Strategic Management Journal, 13(5): 335-349

Amihud Y, Lev B (1981). Risk reduction as a managerial motive for conglomerate mergers. Bell Journal of Economics, 12: 605-617

Ansoff H I (1965). Corporate Strategy: An Analytic Approach to Business Policy for Growth and Expansion. New York: McGraw-Hill

Berger P G, Ofek E (1999). Causes and consequences of corporate refocusing programs. Review of Financial Studies, 12: 311-345

Bettis R A, Hall W K (1982). Diversification strategy, accounting determined risk, and accounting determined return. Academy of Management Journal, 25: 254-264

Chatterjee S, Wernerfelt B (1991). The link between resources and type of diversification: Theory and evidence. Strategic Management Journal, 12(1): 33-48

Christensen H K, Montgomery C A (1981). Corporate economic performance: Diversification strategy vs. market structure. Strategic Management Journal, 2(4): 327-343

Comment R, Gregg J (1995). Corporate focus and stock returns. Journal of Financial Economics, 37: 67-87

Elgers P T, Clark J J (1980). Merger types and Stockholder returns: Additional evidence. Financial management, 9: 715-732

Gregory A (1997). An examination of the long run performance of UK acquiring firms. Journal of Business Finance and Accounting, 24: 971-1002

Hall E H Jr (1995). Corporate diversification and performance: An investigation of causality. 
Australian Journal of Management, 20(1): 25-42

Jensen M C, Meckling W H (1976). Theory of the firm: Managerial behavior, agency costs, and ownership structure. Journal of Financial Economics, (3): 305-360

Kahneman D, Tversky A (1979). Prospect theory: An analysis of decisions under risk. Econometrica, 47: 262-291

Khanna T, Palepu K (2000). Is group affiliation profitable in emerging markets? An analysis of diversified Indian business groups. Journal of Finance, 55: 867-891

Lubatkin M (1987). Merger strategies and stockholder value. Strategic Management Journal, $8(1): 39-53$

Park C (2003). Prior performance characters of related and unrelated acquisitions. Strategic Management Journal, 24: 471-480

Singh H, Montgomery C A (1984). Corporate acquisitions and economic performance. Presented at National Academy of Management Meetings, Boston

Sitkin S B, Pablo A L (1992) Reconceptualizing the determinants of risk behavior. Academy of Management Review, 17(1): 9-38

Teece D J (1981). Internal organization and economic performance: An empirical analysis of the profitability of principal firms. The Journal of Industrial Economics, 30(2): 173-199

Wiersema M F, Bantel K A (1992). Top management team demography and corporate strategic change. Academy of Management Journal, 35(1): 91-121

冯根福, 吴林江 (Feng Genfu, Wu Linjiang) (2000). 我国上市公司并购绩效的实证研究 (An empirical study on M\&A performance of Chinese listed corporation). 经济研究, (1): 54-61, 68

姜付秀 (Jiang Fuxiu) (2006). 我国上市公司多元化经营绩效的决定因素研究(Determinants of diversification by listed firms in China). 管理世界, (5): 128-135

金天，余鹏翼 (Jin Tian, Yu Pengyi) (2005). 股权结构、多元化经营与公司价值: 国内上市公司的 证据检验 (Diversification and company performance: Empirical evidence from China's public companies). 南开管理评论, 8(6): 80-84

李善民, 陈玉罡 (Li Shanmin, Chen Yugang) (2002). 上市公司兼并与收购的财富效应 (Study on wealth effects of M\&A of listed companies). 经济研究, (11): 27-35, 93

李善民, 朱滔 (Li Shanmin, Zhu Tao) (2006). 多元化并购能给股东创造价值吗? 一一兼论影响多 元化并购长期绩效的因素(Can diversification create Value for shareholders?) 管理世界, (3): 129-137

李善民, 曾昭灶, 王彩萍等 (Li Shanmin, Zeng Zhaozao, Wang Caiping) (2004). 上市公司并购 绩效及其影响因素研究 (Study on the performance and the factors of M\&A of Listed Companies). 世界经济, (9): 60-67 